\title{
8
}

\section{Free Trade and Ecology - Benchmarking as a Method Towards a Sustainable Future}

\author{
A.-P. Hameri and E. Eloranta \\ Institute of Industrial Automation, Helsinki University of Technology \\ Otakaari 1, FIN-02150 Espoo, Finland \\ Internet: aph@cs . hut.fi
}

\begin{abstract}
The paper questions whether the prevailing combination of management principles provide ecologically sustainable future. Benchmarking together with the presumptions of free trade and neoclassical economics direct the industrial enterprises to strive towards the best practise and higher profits. To achieve comparative advantage is no longer the main objective of multinational firms, but to obtain supreme advantage through cost efficiency and better exploitation of resources. Free trade with expeditiously moving capital and the increasing use of benchmarking techniques has created a business environment where the legal system is too rigid to provide exogenous and sufficient protection for the nature. We suggest that the external control should itself use benchmarking and shift the obsolete neoclassical world view towards the steady-state economics in order to provide ecologically secured future.
\end{abstract}

Keywords: benchmarking, free trade, neoclassical and steady-state economics, ecology, globalisation

\section{INTRODUCTION - THE GLOBALISATION PROCESS}

The Uruguay round of the General Agreement on Tariffs and Trade (GATT) negotiations at the end of 1993 was a partial success. New members were obtained and better prospects for fluent trade were made. This agreement provides the legislative framework for smooth transition from internationalisation to full globalisation of manufacturing and services. GATT is only a part of the global process that reshapes the operating environments of industrial companies by removing trade barriers between nations. International production through world-wide corporate networks with multimodal supply and distribution chains has marked the current era as the period of physically and logically distributed co-operation. The visible proof of this trajectory of development includes the following things (see e.g. OECD, 1992, p. 211):

- the very rapid growth of foreign direct investment;

- the role played by multinational enterprises in world trade and the present volume of intra-firm trade;

- the emergence of highly concentrated international supply structures;

- the increasing number of cross-border mergers and acquisitions;

- the development trends in managerial principles to manage distributed manufacturing and global competition. 
The GATT pact between 117 countries aims to secure the economic growth and jobs in exportrelated industries worldwide over the next decade by lowering the consumer prices and, most important, by preventing protectionism. As the above list of facts indicate that the companies are already exploiting, and have been for some time, the fruits of free trade and comparative advantage through globalisation. The point of this paper is not to argue whether Japan should allow the import of rise, but how the current managerial principles along with benchmarking direct the economy in the future.

One major reason for the emergence of multinational enterprises stems from the obstacles and disparities between countries. Such obstacles and disparities include tariff barriers, wage and interest rate differentials, technological inequalities, and the fact that national economies are at varying stages of development. These differences between nations provide an opportunity for the multinational enterprises to delocate production and other functional parts of the organisation in such manner that overall cost efficiency is achieved. The increasing use of transaction cost theory has also favored the geographical diversification of multinational companies. The phenomenon is of significant scale even if we only consider the flow of intratriad investment between the three developed market areas in the world (Fig. 1).

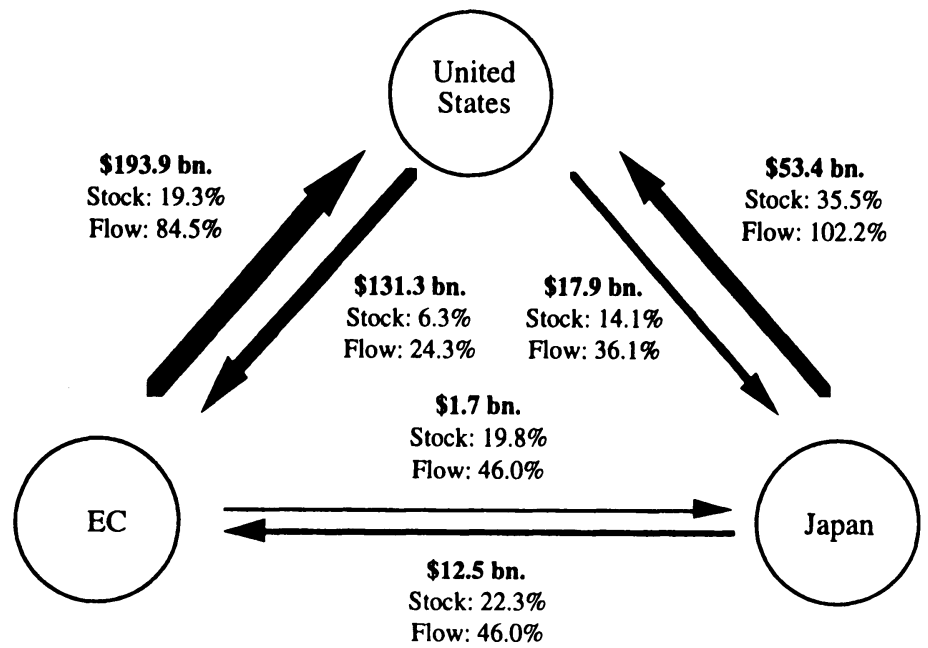

Figure 1. The flow of intra-triad investment, 1985-89 and the 1988 level of stock (source OECD, 1992). Note: Dollar figures show 1988 outward stock; percentages show average annual growth rates, stocks and flows. Stock growth rates are for 1980 to 1988. Flow growth rates are for 1985 to 1989.

The figure shows the evolution inside the developed market areas, which was boosted by the 1980 s financial deregulation and globalised monetary markets. Even more rapid has been the development inside the market areas and in the new and virgin areas of trade. The transition process inside the pan-Europe along with the Baltic states, the former Soviet Union and Eastern Central Europe is very vivid because of their superior economical and operational advantages (labour, raw-materials, finance, etc.). Similar process is going on in America where the North American Free Trade Agreement (NAFTA) aims to standardise the basic elements of competition among the northern-American nations. In the far-East the disparities among rivalling nations, e.g. northern-Korea, has been subject even for open trade-wars. It is beyond the scope of this paper to analyze in more detail the globalisation process and, thus, the paper focuses on the implications of the managerial principles pursuing the companies towards ultimate excellence. 


\section{MANAGERIAL PRINCIPLES - BENCHMARKING}

Management of industrial enterprises have faced many themes and methods that provide a quick-fix for competitivity and success. Eccles et al. (1992) describe nicely the continuous change in the prevailing productivity paradigm of consultants, academics and researchers. Eloranta (1993) points out that these hypes (e.g. just-in-time, theory of constraints, time based competition, lean production, activity based management and costing, logistics, benchmarking, kaizen, computer integrated manufacturing, global sourcing, re-engineering, visual management, concurrent engineering, etc.) share the common message to concentrate on the real and value-adding processes of the company. Of all these hypes benchmarking is currently popular among the companies. According to the word definition benchmarking means something that serves as a standard by which others may be measured and judged. On the other hand it may also mean a standardized problem or test that serves as a basis for evaluation or comparison (e.g. tests for computer system performance). In the measurement of industrial performance benchmarking means the continuous process of measuring products, services and practises against the toughest competitors or those companies recognized as industry leaders to achieve superioir performance. As Camp $(1989$, p. 3) puts it that the essence of benchmarking is to be the best of the best.

There are various levels of benchmarking ranging from strategic and operational benchmarking to the business management benchmarking (Pryor, 1989, p.29). Regardless of the level, the underlying procedure is the same, the emphasis and focus being on different levels or parts of the organisation. By analysing the current performance against the best practise (e.g. market leader) enables to determine the competitive gap. Both negative and positive gaps should be analyzed, yet the negative ones needs to be examined thoroughly to define why differences exist and what factors require change. This analysis phase provides the means to project the future performance levels and the trajectory of the development. The goal is to transform the negative gaps to positive ones and, thus, to gain superior performance over the rivals. Once the goals are set then begins the integration phase, where the benchmarking results are communicated with the organisation. Functional goals and action plans are established for each organisational part that the development affects. Through the understanding of the benchmarking results and the motivation of the personnel the plans are executed. To monitor the development the benchmarks should be recalibrated after certain periods and not only at the end of the project. Therefore benchmarking is a continuous process towards the best practice.

Despite the systemized method of benchmarking (Camp, 1989), it is hard to find good cases of its use in practise. More or less the cases indicate that benchmarking is based on copying methods from other companies, which are doing better. As one consultant declared: "If things are done right, do not hesitate - copy!". Usually the public sources of information provide enough facts on how the rivals are doing certain operations. This is due to the fact that to obtain quantitative and accurate information from competitors is difficult or even impossible. Yet, some world class benchmarking candidates can be easily listed. Pring's (1992) list for the creme de la creme on certain topics is the following:

\begin{tabular}{|l|l|}
\hline Purchasing & Honda Motor, Xerox, NCR \\
\hline Quality process & $\begin{array}{l}\text { Westinghouse, Florida Power \& Light, } \\
\text { Xerox }\end{array}$ \\
\hline Manufacturing operation & $\begin{array}{l}\text { Hewlett-Packard, Corning Inc, Philip } \\
\text { Morris }\end{array}$ \\
\hline Sales management & IBM, Procter \& Gamble, Merck \\
\hline Technology transfer & Square D, 3M, Dow Chemicals \\
\hline Training & Ford, General Electric, Polaroid \\
\hline Warehousing \& Distribution & $\begin{array}{l}\text { L L Bean, Hershey Foods, Mary Kay } \\
\text { Cosmetics }\end{array}$ \\
\hline
\end{tabular}

Table 1. Some world class benchmarking candidates (Pring, 1992). 
In one way or an other the many managerial hypes share directly or indirectly the same sincere objective; to provide means for faster throughput times, better quality and improved cost efficiency. Benchmarking enables companies to asses their current performance with respect to other companies. This kind of comparison differs from the traditional customer surveys and other intra-company analyses, which indicate what customers want and how we are doing it. Thus, the learning by doing method is applied. But this kind of analyses may provide onesided picture of the current situation and the true potential of improvement is not exploited. Benchmarking versatiles the traditional methods, for improvement by enhancing the aspect of learning from others.

\section{ECOLOGICAL IMPLICATIONS - THE MASS PRODUCTION PARADIGM}

In America Ross Perot has warned the people of the "giant sucking sound" that will take effect along the NAFTA. By this he means the huge transition process during which the American industrial enterprises will move their value-adding facilities on to the Mexican territory. Perhaps there will be a real movement phenomenon, but as we know, the movement has been valid for the past 20 years. Along the increase of labour costs in the US companies have been delocating their activities to the cheaper Mexico. Due to this process the famous Rio Grande has partially turned into sewage. This development is simply the result of the continuous search for better cost efficiency and competivity. Along with these driving measures, the lax environmental standards and poorly enforced regulations usually valid in low cost countries speed up this development.

The mass production paradigm is strongly prevailing the current industrial enterprises where the profit making is still largely based on Fordian wisdom of high volumes and low unit costs. Relying on the huge PIMS data base, Eloranta (1993) argues that this attitude is still prevailing, despite the voluminous debate around the customer oriented production systems. The data base shows that customization is statistically the major determinant of low profitability. Thus, the current managerial principles together with bencmarking largely direct the development towards cost efficiency and high volumes. Taiichi Ohno's (1988) sincere idea of production systems generating productivity of mass production at low volumes has not been achieved yet.

Along with this development the comparative advantage of nations work all the time leading probably towards the absolute advantage. As Daly (1993, p. 51) points out that Racardo's theory of free trade between nations has a critical but often forgotten assumption that factors of production (especially capital) are internationally immobile. In reality this is not true, because capital can be moved from nation to nation almost at the speed of light. The following figure depicts the evolution of free trade towards absolute advantage (ibid., p 52). 


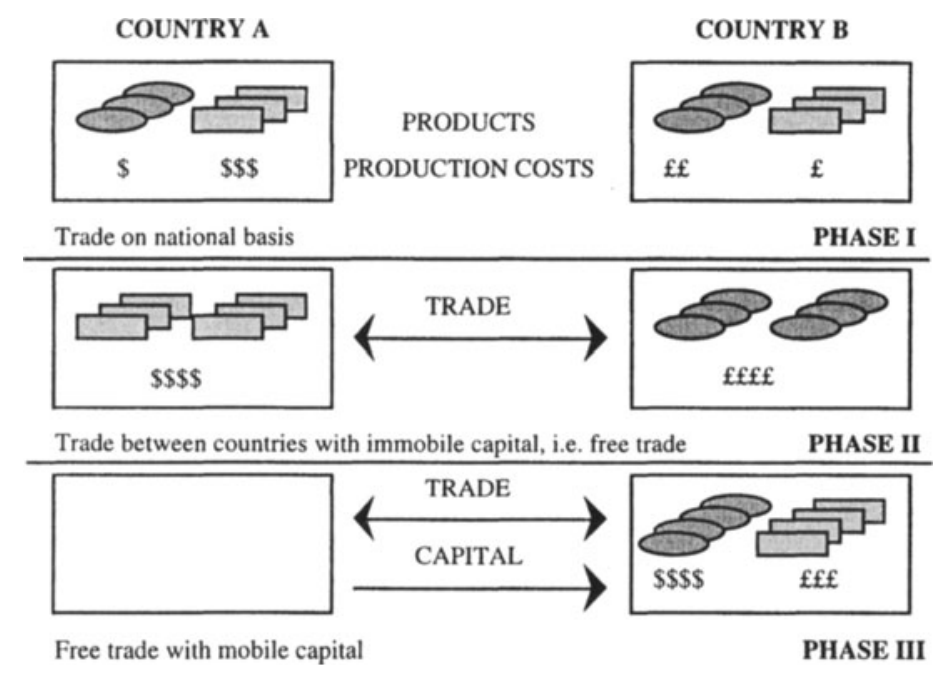

Figure 2. The evolution of trade from national to global through comparative advantage to the absolute advantage (Daly, 1993).

Despite the schematical nature of the picture the rationale is the following:

Phase I Without international trade each country is limited by its own capital and resources. Some products are comparatively less expensive to produce than others on a per unit basis.

Phase II Along the free trade countries can specialise on those products with high comparative advantage. All of country's capital can be invested in making certain products. Absolute cost differences between the countries do not matter. The hidden assumption is that capital cannot cross borders.

Phase III If capital is mobile (as it is), capital may follow absolute advantage rather than comparative advantage. The result may be the one predicted by Ross Perot.

The above dynamics of the development seems to be plausible, yet to verify it is a difficult task. But intuitively without any exhaustive quantitative analysis we can provide evidence of the existence of this development. The following map (Figure 3) depicts the transformation process of Finnish textile companies in the Europe. By viewing the location of factories we may conclude that the driving force has been the cost of labour. 


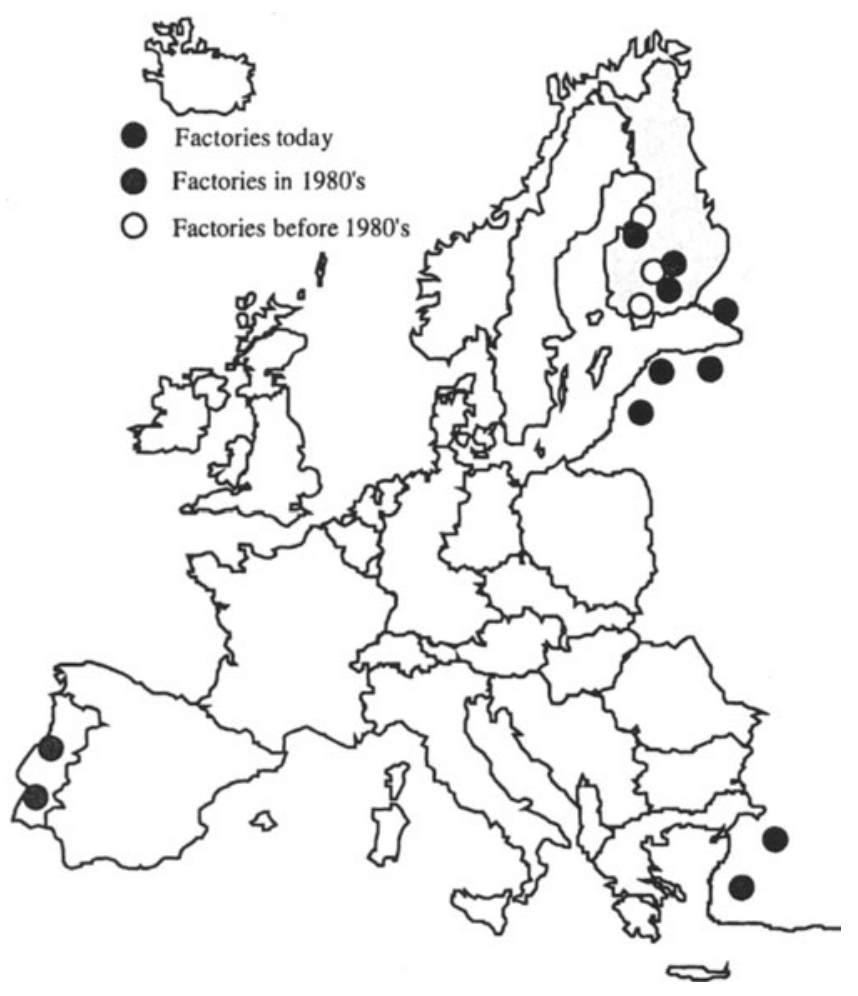

Figure 3. Location of Finnish owned textile factories before, during and after the 1980's.

The map shows nicely the avid pursuit after lower costs. This tendency is emphasised because textile manufacturing is typically very labour intensive industry. Same clustering development could be depicted in other industries and globally the process is very active. Batra (1993) discuses the problems of free trade from the point of view of domestic markets. He proposes that nations should establish strict means to control the trade. As Daly (1993) summarizes it that each country should set the rules of cost internalization in its own market. Whoever sells in a nation's market should play by that nation's rules or pay a tariff sufficient to remove the competitive advantage of lower standards. Thus, tariff policy should consider the environmental preferences and moral judgements between two trading nations.

\section{EXOGENOUS CONTROL - STEADY STATE ECONOMICS}

So far we have reached the conclusion that free trade and current managerial principles are insufficient to provide ecologically sustainable future. The evolution of industrial enterprises is conducted by the mass production and cost efficiency paradigm. The whole economy is driven by the neoclassical principles, which says that ultimately growth will solve all the problems (immigration, exploitation of raw-materials, ecological problems, etc.). Factors of production are changed into goods and services and this circle of transformation is the whole economy. The system is isolated and thus can be of any size. The unrealistic equilibrium position of an economy with continuous growth expectations is the object of study for neoclassical economics, which has resulted in many "armchair" analyses and mathematical models of this hypothetical situation (for summarizing critique see e.g. Simon, 1983, pp. 13-14; 1986, pp. 22-24). As a former neoclassical economist Boulding (1991, p. 12) hilariously puts it “... we 
got trapped into what I have called a 'cookbook theory' of production, that we mix land, labour and capital, and out pops potatoes or microwave ovens". To broaden the view of neoclassical economics new approaches have been developed. One mainstrem is the evolutionary economics which have strong emphasis on technological issues as the core of economoc and ecological development.

The neoschumpeterian school (see e.g. Dosi et al., 1988; Freeman \& Soete, 1990; Hagedoorn, 1989; Stolper, 1991) have broken the untouched core of the economic system using an empirical approach and delivering real world data of the consequences and nature of technological changes and innovations. The idea that economies should be understood on the basis of the 'evolutionary paradigm', rather than an equilibrium situation or a world of deterministic mechanics has become a prevailing attitude in this research. This work has also created a whole set of new concepts describing technology and technological process. The approach adopted by neoscumpeterian research has also extended the narrow presumptions of the neoclassical models of economic growth. The Nelson-Winter (1982) 'evolutionary' model of technical choice and innovation is one result of the theoretical work of this economic school. In their model, disequilibrium, which is understood as an important characteristic of economic development, plays a central role. Competition is no longer seen as a static phenomenon but a process in which winners and losers are generated. The winning companies have the carpe diem characteristics of taking advantage of technological opportunities, while the losers will miss their chances and gradually decline into technological obsolesce. This school has also extended their research on to the ecological issues.

Traditionally, the only methods of appraisal in technology have been based on economic and efficiency criteria, set by the engineers and entrepreneurs. This is due to the obsolete attitude that nature is seen as a finite resource which must be fully utilized. The study of technology assessment is a pursuit to find an appropriate regulatory framework to restrict the risks and costs and to enhance the benefits of technological change. To construct such a framework, all the different and diverse aspects of technologies, must be comprised. As Naschold (1991, p. 73) simply declares, the whole effort of technology assessment is to obtain a better understanding of the complex processes of technological change and, where possible or necessary, to steer or shape these processes. The interest towards technology evaluation has increased, perhaps because of the common awareness of the already realized and the possible negative effects of technological development. Hawthorne (1978, p. 168) specifies more accurately the above general criteria of technology assessment. He classifies technology assessment into categories which include:

- quality of life; impact of technology on individuals,

- $\quad$ social structure; changes in infrastructure and institutional systems,

- external environment; human health and safety together with the natural environment,

- working environment; employment and working conditions,

- alternatives; optional technologies,

- $\quad$ assessment effectiveness; measuring the management performance.

Technology assessment is the tool to guide our economic system towards the steady-state view of economy, according which the economy is only one component of a larger ecosystem in which materials are transformed and energy is converted to heat. As the economy grows larger, its behaviour must conform more closely to that of the total ecosystem. The economy is seen to be one open subsystem in a finite, nongrowing and materially closed system. Being an open subsystem it must be controlled exogenously by providing certain economic incentives, such as pollution taxes or tradeable emission permits. For the policy and regulation makers benchmarking may provide a tool to find the best practises in ecological performance among industrial enterprises. At least the following best practises on each line of business could be tracked by using benchmarking:

- the best recycling performance;

- the best energy efficiency; 
- the best production methods and procedures enabling minimum air and water pollution;

- the best organizational modes and wage scales for human friendly work environment.

In addition to these analyses benchmarking could also be used on national basis:

- which country has ecologically the most advanced legislation system;

- which taxation system provides the best incentives for industrial enterprises to develop ecologically sustainable technologies.

As the OECD (1992, p. 208) report concludes that technology policy can become increasingly important instrument in attaining environmental objectives. More cross-sectoral, multidisciplinary approaches are called for. Thus, the apparent threats of future may be turned to possibilities in a sustainble growth trajectory.

\section{CONCLUSIONS}

Benchmarking is seen as a method which emphases learning from those who are industry leaders in certain functional performance. This principle along with the traditional and still strongly prevailing mass production paradigm with its managerial principles has initiated the globalisation process. Various free trade agreements will speed up this process, when the search for comparative advantage may change to avid pursuit on absolute advantage. From the ecological point view this development is unfortunate and certainly it is not a sustainable one. It is suggested that the obsolete neoclassical view of economic system is to be changed into steady-state economic approach. To control and direct the economic development towards more sustainable future the policy makers should itself use benchmarking methods to discover environmentally friendly production technologies and to provide legislative means to direct industries to adopt these technologies. From the traditional production management point of view the success factors will remain the same; speed and quality in every operation is the key to prosperity also in the future.

\section{REFERENCES}

Batra, R., Myths and Misconseptions of Free Trade, Scribner's, 1993.

Boulding, K.E., "What is evolutionary economics?", Journal of Evolutionary Economics, vol. 1, pp. 9-17, 1991.

Camp, R.C., Benchmarking - The Search for Industry Best Practises That Lead to Superior Performance, ASQC Quality Press, Milwaukee, Wisconsin, 1989.

Daly, H.E., "The Perils of Free Trade", Scientific American, pp. 50-57, November, 1993.

Dosi, G., Freeman, C., Nelson, R., Silverberg, G., Soete, L. (eds), Technical Change and Economic Theory, London, Pinter Publishers, 1988.

Eccles, R., Nohira, N., Berkeley, J., Beyond the Hype - Rediscovering the Essence of Management, Harvard Business School Press, 1992.

Eloranta, E., "Value-Adding Factory - A View on the Factory-of-the-Future", paper presented at the Third International IMS Symposium in Vienna, Austria, 30.11.-1.12.1993.

Freeman, C., Soete, L. (eds), New Explorations in the Economics of Technical Change, London, Pinter Publishers, 1990.

Hagedoorn, J., The dynamic Analysis of Innovation and Diffusion, London, Pinter, 1989.

Hawthorne, E.P., The Management of Technology, Maidenhead, McGraw-Hill, 1978.

Naschold, F., "Techno-Industrial Innovation and Technology Assessment - The State's Problems with its New Role", in Hilpert, U. (ed), State Policies and Techno-Industrial Innovation, London, Routledge, pp. 65-82, 1991. 
Nelson, R.R., Winter, S.G., An Evolutionary Theory of Economic Change, Cambridge, The Belknap Press of Harvard University Press, 1982.

OECD, Technology and the Economy - The Key Relationships, TEP - The Technology/Economy Programme, Paris, 1992.

Ohno, T., Workplace management, Productivity Press, Cambridge Mass., 1988.

Pring, P., "Benchmarking Strategy for Business Improvement - a 3M View", the IIR Seminar on benchmarking, Helsinki, Finland, 11.6.1992.

Pryor, L.S., "Benchmarking: A Self-Improvement Strategy", The Journal of Business Strategy, November/December, pp. 28-32, 1989.

Simon, H.A., Reason in Human Affairs, Stanford, Stanford University Press, 1983.

Simon, H.A., "On the Behavioral and Rational Foundations af Economic Dynamics", in Day, R.D., Eliasson, G., The Dynamics of Market Economies, Amsterdam, Elsevier Science Publishers, pp. 21-41, 1986.

Stolper, W.F., "The theoretical bases of economic policy: the Schumpeterian perspective", Journal of Evolutionary Economics, vol. 1, pp. 189-205, 1991. 